\title{
オフィスワーカーのリフレッ シュの現状について
}

\section{RE : ACTUAL SITUATION OF REFRESHMENT IN OFFICE}

\author{
大山能永 一 $* 1$ \\ 中村芳樹 — $* 3$ \\ 森川泰成 — $* 2$ \\ キーワード \\ アンケート，オフィス環境，リフレッシュ
}

Keywords :

Questionnaire, Office, Refreshment

\section{Yoshie OYAMA $-* 1 \quad$ Yasushige MORIKAWA $-* 2$ \\ Yoshiki NAKAMURA $-* 3$}

We carried out questionnaires to make clear actual situations how the office workers took for a change (to refresh themselves). $95.4 \%$ of office workers regarded a refreshment as a requirement, and $83.7 \%$ had actually refreshed themselves in the office. Especially people thought that refreshing gave a clue to the solution. Many workers took a break for a refreshment at their desks or in washrooms, with drinking, chattering and looking out of the windows for 10 minutes or less. They thought that a window was important in the room for a refreshment. A lot of valuable information to design rooms for a refreshment was obtained.

\section{1.はじめに}

情報機器の進化が著しく、情報機器で処理される単純な作業は 日々増えている。より知的な創造業務の遂行と情報機器に関する 学習を、常に求められる現代のオフィスワーカー（以後、ワー カーとする）のストレスは増大し、リフレッシュの重要性が高 まっているのではなかろうか。

約10年前、オフィスは企業の顔や生活の場としての観点から盛 んにリニューアルされた。このような傾向が執務エリアから他の 空間へと拡がろうとしていた時、我が国の経済状況が悪化し、リ ニューアルの勢いは止まってしまった。リニューアルが盛んだっ た1991年頃、オフィスを知的生活の空間として捉え、オフィスで のリフレッシュについてアンケート調査が行なわれた*1。そし て、昨今の調査でも「気分転換の場がない」という不満が報告さ れている*2。

そこで、現代におけるオフィスでのリフレッシュの必要性を検 討するために、ワーカーが[どのようにリフレッシュを考え]、[ど のようにリフレッシュしているがについてのアンケートを行っ た。筆者の知る限り、1991年の調査以降リフレッシュに関する詳 細なアンケート調查は報告されていないので、1991年の調査結果 と比較することにより、傾向が推察できるように1991年の調査結 果もなるべく引用した。その際に1991年の調査結果を以前の結果 と記述した。なお、本研究においては昼休嚊はリフレッシュに含 まない。

本アンケートの結果が、オフィスでのリフレッシュの実情を明 らかにするだけでなく、オフィス以外の建物に設けるリフレッ シュ空間の設計資料にもなると考え、その結果を報告する。

\section{2. アンケート概要}

\section{1 対象者}

アンケートの回答者は都市部所在の 12 事業所（東京/千葉/さい たま/大阪/名古屋/福岡/札幌/仙台/広島/横浜/新潟/高松）に勤 務するワーカーである。彼らは某建設会社の内勤の事務職社員で ある。勤務先は賃貸事務所ビルの複数階占有か自社ビルで女る。

596 人に配布、326人より回答を得られたので、回収率は $54.7 \%$ であった。回答者の属性を表 1 に示す。

役職の選択肢非管理職/管理職（課長以上）としたところ、課長 以上ではあるが部室長でない多くの人が回答に迷い、無回答にし てしまった注。

\section{2 アンケート方法}

アンケートの配布および回答には、社内の情報伝達などのため に利用されている社内限定インターネット（以後、イントラネッ トとする）を利用した。イントラネットにより回答者各自にメイ ルが配信され、そのメイルの添付書類としてアンケートの設問 ファイルが届く。設問ファイルを開き、選択肢を選ぶことが回答 となり、最後に返信してもらった。

回答途中で中断できず、設問ファイルがテキストファイルであ 表1 回答者の属性

\begin{tabular}{|l|l|r|l|}
\hline \multirow{2}{*}{ 性別 } & 男性 & 女性 & 無回答 \\
\cline { 2 - 4 } & 206 & 119 & \multicolumn{1}{|c|}{1} \\
\hline 役職 & 管理職 & 非管理職 & 無回答 \\
\cline { 2 - 4 } & 91 & 169 & \multicolumn{2}{|c}{66} \\
\hline
\end{tabular}

\footnotetext{
*1 Research Engineer, Technology Center, Taisei Corporation, M. Eng.

*2 Research Engineer, Technology Center, Taisei Corporation, Dr. Eng.

*3 Assoc. Prof., Department of Built Environment, Interdisciplinary Graduate School of Science and Engineering, Tokyo Institute of Technology, Dr. Eng.
}

*1 大成建設侏技術センター 研究員・工修

( T245-0051 横浜市戸塚区名瀬町344-1)

*3 東京工業大学大学院総合理工学研究科人間環境システム 助教授・ 工博 
るなど回答意欲を向上させる配慮がしにくい方法にも関わらず高 い回収率が得られたことにテーマへの関心の高さが感じられる。

\section{3 アンケートと項目と回答方法}

アンケートでは、1）リフレッシュの必要性、2) 現状を明らかに するための設問と選択肢を用意した。リフレッシュの必要性で は、業務を特定しない場合と知的創造業務に特定した場合両方で リフレッシュの必要性を問いた。リフレッシュの現状では時刻、 所要時間、場所を個別に尋ねた。具体的な設問と選択肢を図 1 に 示す。

\section{3. アンケート結果}

\section{1 リフレッシュの必要性}

95.4\%のワーカーがリフレッシュを必要なものと意識している ことがわかった(図2)。以前の結果では66\%と報告されている*1の で、リフレッシュを必要と考えるワーカーの割合がこの約 10 年で 増大したことがわかる。

業務によってリフレッシュが異なるかについては、 $58.3 \%$ の人 が異なると回答し、39.0\%の人が異ならないと回答した（無回答 は2.8\%)（図3）。

何のためにリフレッシュが必要かについては、用意した 7 つの
選択肢から3つ以下を選択させた所、4つ以上を選択した被験者が 23 人（4 選択が 8 人、 5 つ選択が 3 人、6 6 選択が 4 人、7つとも 選択が8人）いた。これらの選択肢は1991年のアンケートの選択 肢に準拠した。用意した選択肢以外の具体的な目的を回答した人 は4人と少なかったので、選択肢に不足はなかったと考える。

最も多い回答が得られたのは気分転換 $(72.7 \%)$ で、次に多かっ たのは精神疲労回復 $(50.3 \%) 、$ 仕事の活性 $(45.4 \%) 、$ 発想転換 (43.6\%)であった。反対に最も少なかったのは仕事からの解放 (11.4\%) で、次に少なかったのはストレス解消（23.6\%）と肉

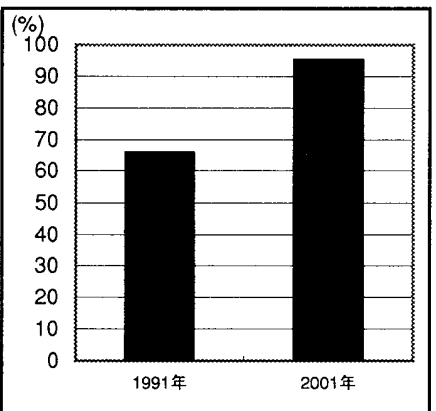

図2 リフレッシュを必要だと思う

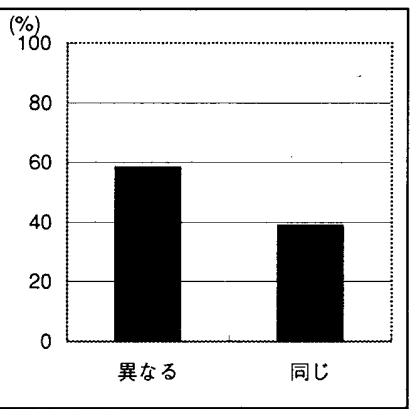

図3業務によって
リフレッシュは異なるか

\section{全員対象の設問}

リフレッシュは

必要だと思いますか?

Yes $\rightarrow$

\section{リフレッシュは何のために必要だと思いま
リフレッシュの必要性は業務によって異な
ると思いますか?}

リフレッシュをとる時刻が会社（事業所）によって指示されていますか？
リフレッシュをとる場所が 会社 (事業所) によって 指示されていますか? あなたはリフレッシュを とっていますか? （選択肢4）
そこは執務空間と独立した空間ですか？(選択肢2）

Yes $\rightarrow$
Yes $\rightarrow$
Yes $\rightarrow$
らない以外 $\rightarrow$
らない以外 $\rightarrow$
らない以外 $\rightarrow$
らない以外 $\rightarrow$
らない以外 $\rightarrow$

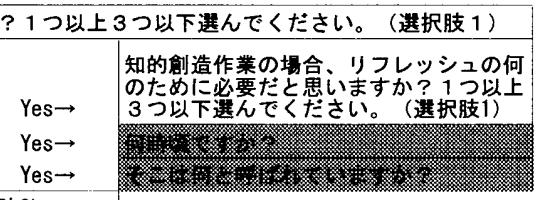

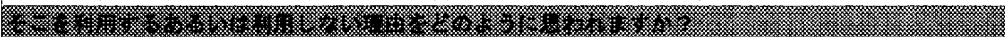

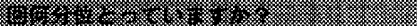

どこでリフレッシュをとっていますか？1つ以上 3 つ以下選んでください。（選択肢5）

リフレッシュをとるために最もよく利用しているところはリフレッシュしやすいですか？（選択肢7) しにくい以外

リフレッシュをとることによって、知的刽造カを向上されたと感したことがありますか？ 何時頃のリフレッシュが知的㓣造カへの向上に有効だと思いますか？(選択肢8) 何分のリフレッシュが知的刢造カへの向上に有効だと思いますか？(選択肢9）

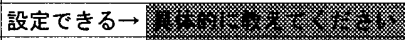

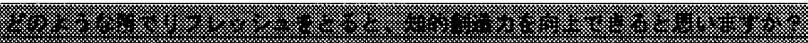
設定できるい

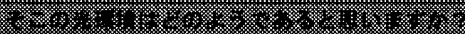

リフレッシュしやすい印象と関係ありそうな視賞的印象を選んでください（複数可）。（選択肢10） リフレッシュしにくい印象亡関係ありそうな視觉的印象を選んでください（複数可）。（選択肢10） どこでリフレッシュしようか決める時、その空間がリフレッシュしやすそうな視觉的印象であることは重要ですか？ Yes

リフレッシュしやすそうな視賞的印象だったのに、リフレッ シュしにくかった体験はありますか? Yes $\rightarrow$ リフレッシュ空間の写真やビデオで、その空間のリフレッシュしやすさの目安はわかると思いますか? リフレッシュ空間の㥶の必要性について（選択肢11） 条件によってはなくてもよい

$\downarrow$

あてはまるものを複数選択（選択肢12）

リフレッシュ空間の光環境の重要性について（選択肢13）

注：網掛は自由記述回答の設問を示す。
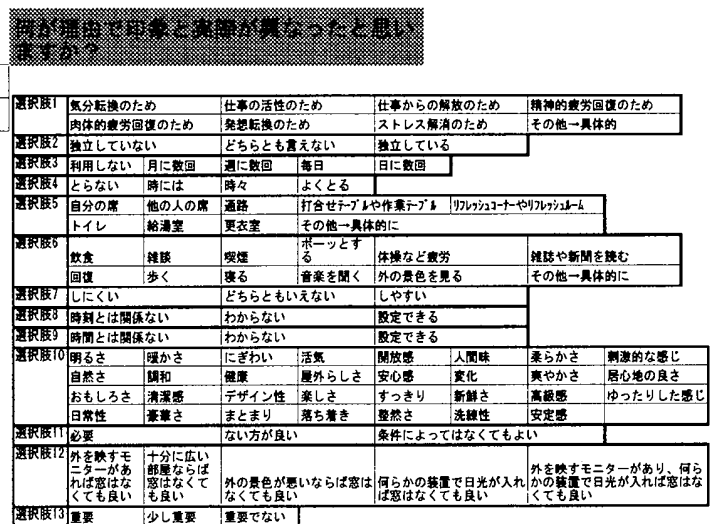

図1＼cjkstart設問と選択肢 


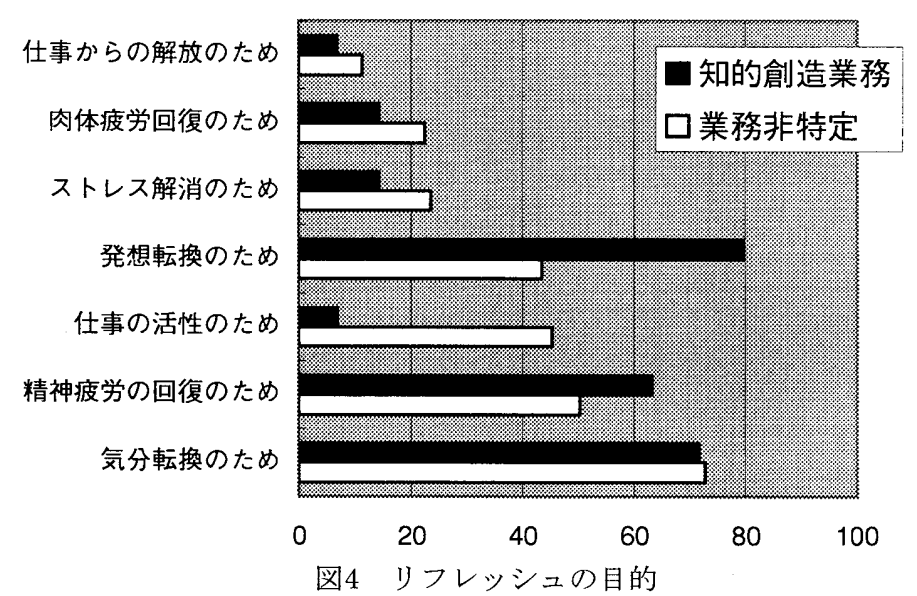

体的疲労 (22.4\%) であった(図4、白い棒)。括弧内の数字はリ フレッシュを必要と回答した人に対する割合である。

これらのことから、多くのワーカーは気分転換や精神疲労回 復、仕事の活性、発想転換のためにリフレッシュを必要と考えて いることがわかった。以前の結果でも多くのワーカーが気分転換 や仕事の活性、仕事からの解放のためにリフレッシュを必要と答 えたと報告されている*1。しかし、精神疲労の回復や発想転換を 理由にあげたものは気分転換の $1 / 3$ と少なかったようで、リフレッ シュの必要性もこの10年間で変化したことがわかる。

また、業務を知的創造業務に特定すると、発想転換のためのリ フレッシュが増えていることが図4の黒棒によりわかる。反対に、 仕事の活性のためのリフレッシュは減っている。

一方、「リフレッシュによる知的創造力の向上の経験の有無」 を聞いた結果、図5に示すように経験のある人が $65.3 \%$ 、ない人 が23. $0 \%$ でった.

これらのことから、多くのワーカーが知的創造業務では発想転 換のためにリフレッシュが有効と考えており、実際にリフレッ シュにより知的創造力の向上の経験をしていることがわかった。

\section{2 リフレッシュの現状}

\section{(1) リフレッシュをとっているか}

リフレッシュをとっているかどうかを聞いた結果、 $83.7 \%$ 年 とっていると回答し（図6）、約3/4のワーカーが[時々]か[時に

は]の割合でリフレッシュをとっていることがわかった。

\section{(2) リフレッシュの時刻と場所の指定}

事業所によってリフレッシュの時刻が決められている人は 4.0 \%と少なく、94. 8\%が決められていないと回答した。決められて いると答えた人に、その時刻の具体的な記述を求めたところ、15 時（5人）と逐次指示される（2人）であった。昼休蒩はリフレッ シュに含まないと明示したが、12時と申告した者が 2 人いた。

また、事業所によってリフレッシュの場所が決められている人

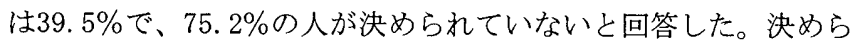
れていると答えた 31 人にその場所の具体的な記述を求めた所、27 人から下記のような回答を得られた。

最も多い回答はリフレッシュコーナーの 11 人で、喫煙所コー ナーが 9 人（喫煙所の7人を含む）、休咊室（更衣室との兼用を含 む） 3 人、給茶器コーナーやリフレッシュルームがそれぞれ 1 人 だった。

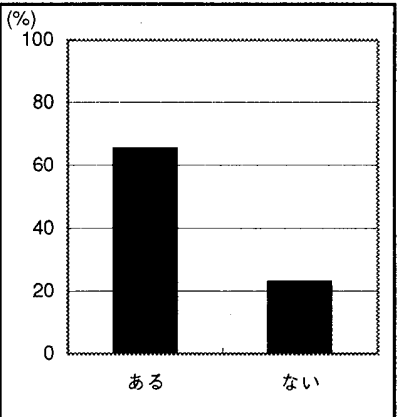

図5 リフレッシュによる知的創造力向上の経験

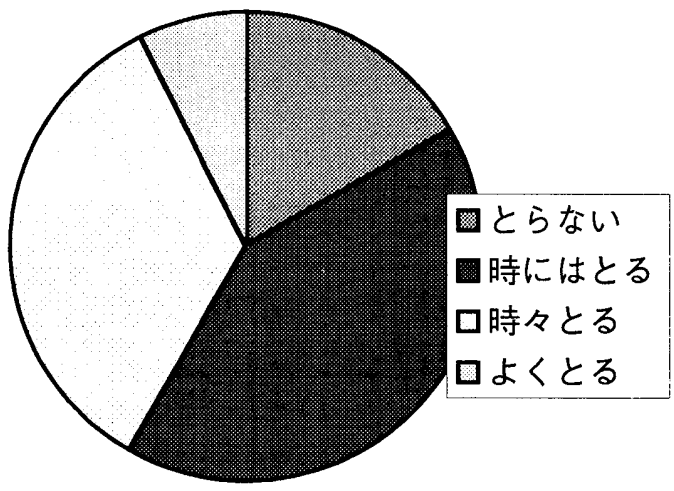

図6 リフレッシュによる知的創造力向上の経験

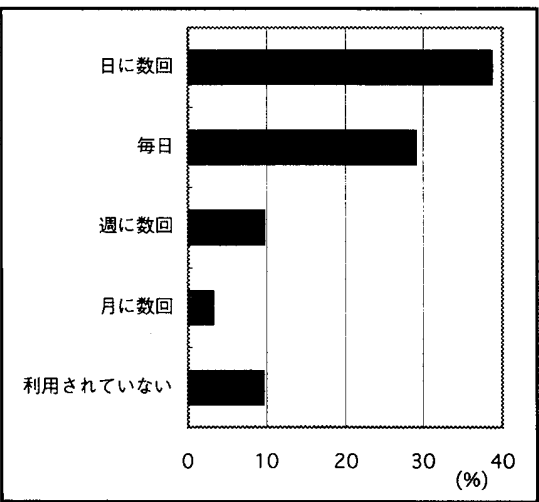

図7 事業所指定のリフレッシュ空間の利用頻度

また、これらの空間が独立していないが $12.9 \%$ 、独立している が $58.1 \%$ 、どちらともいえないが $29.0 \%$ であた。以前の結果で は、独立していないが $37 \%$ 、独立しているが $63 \%$ と報告されてい る*2ので、リフレッシュのための空間の半数以上が独立していな い点では、この10年間に変化しなかったことがわかる。

これらの空間が人々に利用されている頻度を図7に示す。図7よ り、12.8\%のワーカーは指定されたリフレッシュ架間の利用頻度 が月に数回以下と思っていることがわかる。

この場所を利用する人には利用する理由を、利用しない人には 利用しない理由を尋ねた所、共にその場所が喫煙場所になってい ることが挙げられた。即ち、事業所では執務エリアを禁煙とし、 リフレッシュのための空間でのみ喫煙を許可しているため、リフ レッシュのための空間を利用寸る人が喫煙者に限られ、非喫煙者 は利用できない状況になっているようだ。 


\section{（3）リフレッシュの時刻と所要時間}

リフレッシュをとる時刻について聞いた所、不特定が $31.1 \%$ （85人）と最も多く、インターバル時間を回答した者（5人）もい た。最も多くのリフレッシュ行為が見られる時刻を設定するとし たら、14:00〜16:00であった。この時間帯を申告した人数は、15 時と申告した 18 人と $14: 00 、 15: 30 、 15: 00 〜 16: 00$ 申告した 33 人 の合計51人であった。また、10:00〜11:00を申告した者も7人 (10:00、10:30、10:50を申告した者を含む) もいた。

1 回あたりの所要時間については、不定と申告した者は 10 人と 少なく、5分以下が 142 人（5 分と申告した 80 人を含む）、10分以 下が151人（10分と申告した 112 人を含む）であった。申告された 中で最も長い所要時間は30分で、申告者数は7人であった。

以上の事から、リフレッシュは14:00〜16:00に行なわれやす く、その所要時間は10分以下であることがわかった。

（4）リフレッシュをどこでとっているか

リフレッシュをどこでとっているかを明らかにするために、自 分の席や、他の人の席など 8 つ選択肢から 1 つ以上 3 つ以下で 選択させた。回答者は、頻度に関係なくリフレッシュをとると回 答した回答者、すなわちリフレッシュをとらないと回答した回答 者以外の全員である。

用意した選択肢に不足のある場合は、具体的に記述させた結 果、非常階段や食堂、屋上、空いている応接室、給茶機のそば、 喫煙席の 7 つが 記述された。

最も多くの人が利用している空間は、自分の席 $(46.5 \%)$ やトイ レ(26.0\%)で、通路や給湯室も約 $8 \%$ あった(図 8$) 。$

最もよく利用している場所の利用しやすさを尋るたところ、利 用しや寸いと回答した者の割合は $10.6 \%$ 、しにくいと回答した者 の割合が $33.7 \%$ 、どちらとも言えないと回答した者が $51.0 \%$ で あった。

このことから、利用しにくいと感じているにも関わらず自分の 席やトイレなどでリフレッシュをとらざる得ないワーカーの現状 がわかる。

利用しやすいための要件を記述させた所、その場がリフレッ シュ専用空間である（仕事中の他者への気兼ね不要を含む）（5 人）、喫煙できる（3人）、自席からの移動（場所を変えるという 意味を含む）（6 人）、一人になれる（他者の目が気にならない を含む）(12人)が挙げられた。空間の建築環境側面では、広い （2人）、静か（2人）、開放感がある（1人）、外の景色が見える (1人)、落ち着ける（1人）が挙げられた。

(5) リフレッシュをどのようにとっているか

リフレッシュをどのようにとっているかを明らかにするため に、飲食や雑談など11の行為から 1 つ以上 3 つ以下で選択させ た。用意した選択肢に不足のある場合は具体的に記述させた所、 顔を洗う、化粧直し、インターネット（6人）、仮眠などの行為が 記述された。最も多く回答された行為は、雑談 $(34.8 \%)$ とボーッ とする $(34.7 \%)$ であった。次に多かったのが、飲食する $(33.0$ $\%$ 、喫煙 $(27.8 \%) 、$ 外の景色を見る $(26.7 \%)$ であった。

以前の結果でも、飲食 $(27.4 \%)$ 、雑談 $(24.0 \%)$ 、喫煙 (17.8\%) は多かったが、ボーッとするは $14.0 \%$ 、外の景色を見 るは2.4\%と少なかった。
雑談や飲食、喫煙がリフレッシュ時の行為であることは約 10 年 前と変わらないが、ボーッとする、外の景色を見る、インター ネットをするなどの行為がリフレッシュ時の行為に追加されたこ とがわかった。

\section{3 リフレッシュ空間の視覚的印象}

\section{（1）リフレッシュ空間選択時の空間の視覚的印象の重要性}

「どこでリフレッシュしようか決める時に、その空間がリ フレッシュしやすそうな視覚的印象であることは重要か」と 質問した結果、重要だと回答した者は $72.1 \%$ 、重要でない と回答した者は $19.0 \%$ あっあた。

\section{(2) リフレッシュしやすそうな視覚的印象}

リフレッシュしや寸そうな視覚的印象 (以降、リフレッシュ しやすさとする)とはどのような視覚的印象であるのかを明ら かにするために、既往研究*3より選択した 31 の視覚的印象か ら、リフレッシュしやすさと関係づけられる視覚的印象とリ フレッシュしにくそうな視覚的印象と関係づけられる視覚的 印象をそれぞれ複数（指定なし）選択させた。

リフレッシュしやすさと関係づけられるとして選択した人 数から、リフレッシュしにくそうな視覚的印象と関係づけら れるとして選択した人数を引いた数値を、リフレッシュしや すさとの関係性とした。

リフレッシュしやすさとの関係性を強いものから列挙した (表2）。表2より、開放感や居心地の良さ、ゆったりとした感 じ、落ち着き、明るさ、自然さなどがリフレッシュしやすさ と近いことがわかった。反対に、にぎわい、豪華、刺激的な 感じなどがリフレッシュしにくそうな視覚的印象と近いこと がわかった。

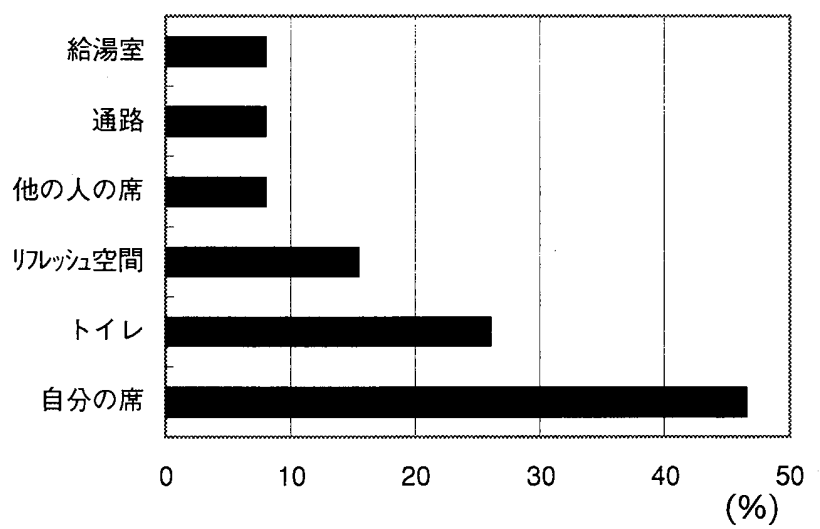

図8 実際にリフレッシュをとっている場所

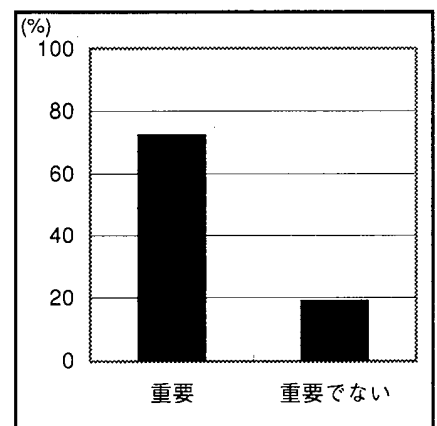

図9 リフレッシュ空間選択時の視覚的印象の重要性 
「太陽の直射光が射し込み・・中略・・何か気持ちの良さ や、気分転換できるような印象」を「リフレッシュ感」と定 義づけ、「リフレッシュ感」が安らぎ、快い、親しみ、居心 地の良さ、解放感、楽しさ、のんびりした感じなどの尺度と の高い相関を報告している既往研究 ${ }^{* 4}$ と、本調査の結果と一致 している。

(3) リフレッシュしやすさと実際のリフレッシュ

リフレッシュ空間の写真やビデオで、その空間のリフレッ シュしやすさの目安がわかるかという問いに対しては、 46.6 \%の者が目安がわかると答え、38.0\%の者は目安がわからな いと答えた。15.4\%の者が無回答であった。

目安がわかると答えた者に、[リフレッシュしやすそうな視 覚的印象だったにも関わらず、実際にリフレッシュしてみた らリフレッシュしにくかった経験の有無]を尋㸚た所、経験の ある者が $32.3 \%$ 、ない者が $67.7 \%$ であった。

[リフレッシュしやすそうな視覚的印象だったにも関わら ず、実際にリフレッシュしてみたらリフレッシュしにくかっ た経験」のある者に、その原因をどのように思うかと記述させ た。その結果、他の人の存在に起因すること（20人）や、不 快な室温や匂い $(12$ 人) 、音環境 $(7$ 人) 、椅子の座り心地

（6人）など視覚だけでは捉えられない要素によることがわ かった。

3-4 リフレッシュ空間の要件

（1）リフレッシュ空間の光環境の重要性

リフレッシュ空間では光環境が重要だと思うかどうかを尋ねた 所、62.9\%が重要と答え、重要でないと答えたものは2. $8 \%$ であっ た。どちらでもないと答えたものが $27.0 \%$ と多かったのは、光環境 の意味がわかりにくかったのかも知れない。

\section{（2）リフレッシュ空間での窓の必要性と代替可能性}

リフレッシュ空間に空が必要かどうかについては、 $72.4 \%$ 多必要 と答え、無い方がいいと答えた者が $0.6 \%$ 、条件によっては無くても 良いと答えた者が19.3\%であった（図11)。

空が無くても良い条件を選択 (複数可) させた所、図 12 に示 すような結果が得られた。屋外の景色が悪ければ空は不要と 回答した者が最も多く $54.0 \%$ 、空間が十分に広ければ不要 と回答した者が $38.1 \%$ 、何らかの装置で日光を導入できれば

表2＼cjkstart視覚的印象としてのリフレッシュしやすさ
不要亡回答した者が36.5\%であった。一方、「外を映すモニ ターがあれば空は無くて良い」と回答した者が7. $9 \%$ と最も少 なかった。

何らかの装置で日光を導入できれば空を不要と回答した者 が36.5\%いたにも関わらず、外を映すモニターを付加した場 合、空を不要とする者が増えず、少なくなった。この理由を 日光を導入する装置や外を映すモニターという環境整備のた めの機械がリフレッシュ空間に多いことを好ましくないと感 じたためと推測する。

この結果は、地下や屋外の景色が悪い所に設けるリフレッ シュ空間のつくり方の資料となるであろう。

以上のことから、空間の広さや、屋外の景色の美醜、日光 照射の有無が空の重要性に関係することがわかった。

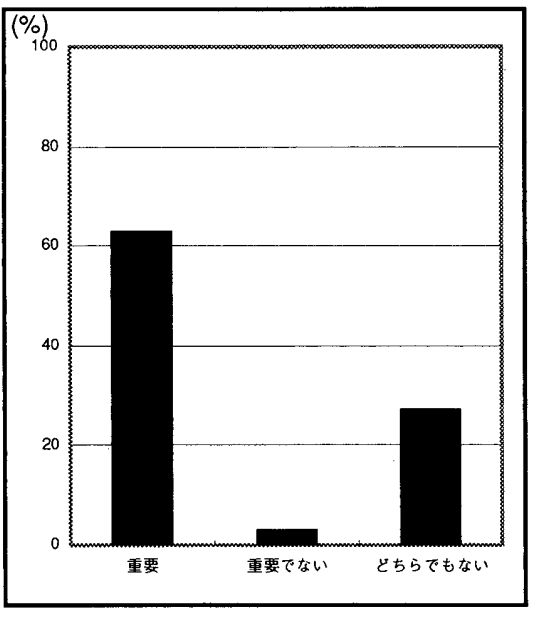

図10 リフレッシュ空間の光環境の重要性

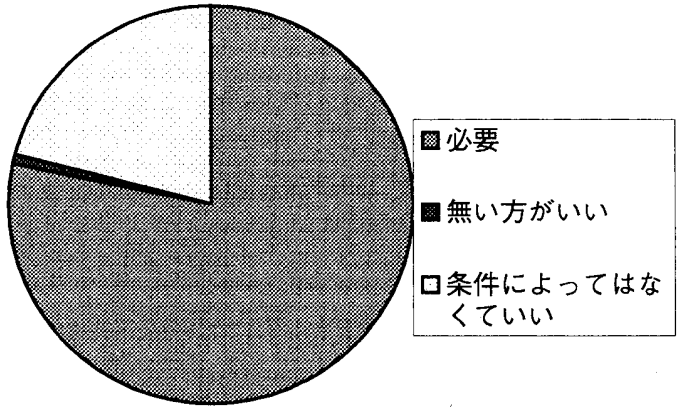

図11 リフレッシュ空間の空の必要性 


\section{(3)リフレッシュ空間における悹の価値}

空の有無、空から臨める景色の美醜、直射日光照射の有無 がリフレッシュ空間としての選択にどの程度影響するかを相 対比較するために、「リフレッシュするとしてどちらの空間 を選ぶか」という一対比較を行わせた。通常の一対比較では 比較回数が多くなり、回答者の負担が大きいので下記の 9 回 のみの比較とした。

x) 北空で空外の景色の美しくない3 室 (3、6、12畳) そ れぞれと 6 畳無空室との比較（計 3 回）

y) 空外の景色悪い場合の南悹から日の入る 3 室（3、6、 12盢）それぞれと 6 畳北空室との比較（計 3 回）

Z) 空から日の入らない北空の場合、悹外の景色の美しく ない 3 室 $(3 、 6 、 12$ 畳) それぞれと空外の景色の美しい 6 畳室との比較（計 3 回）

どちらが選択されたか（選択割合）を表3に示す。表3で は、50\%以上選択された場合を薄い網掛で、80\%以上選択さ れた場合を濃い網掛で示した。

表3より、下記のことがわかった。

・空外の景色が悪く空からの直射日光がない場合、3畳 の北空室は 6 畳の無空の室と同等以上の選択率が得ら れ、同じ 6 畳ならば北空のある室の方を $70 \%$ 以上の人が 選択する。

・ 6 畳無空室より、空外の景色が悪くても空からの直射 日光がある 3 畳の室を選択する人が半数以上いる。

・同じ 6 畳で空外の景色が悪い場合、北空より南空のあ る室方を $70 \%$ 以上の人が選択する。

・空から直射日光の照射が期待できない北空の場合、空 外の景色の悪い12畳よりも空外の景色の美しい6 畳の方 を選ぶ人が70\%以上いる。

選択割合を $\mathrm{Y}$ と、広さの冨数を $\mathrm{x}$ とする回帰分析を行っ た。その結果、下記の回帰式が得られた。

・無空室との比較

$\mathrm{Y}=18.683 \operatorname{Ln}(\mathrm{x})+29.091\left(\mathrm{R}^{\sim} 2=0.724\right) 、$

・直射日光の有無の比較

$\mathrm{Y}=13.498 \mathrm{Ln}(\mathrm{x})+42.38\left(\mathrm{R}^{\sim} 2=0.811\right)$ 、

- 景色の美醜の比較

$\mathrm{Y}=0.4428 \mathrm{e}^{\wedge} 0.2472 \mathrm{x}\left(\mathrm{R}^{\sim} 2=0.745\right)$

それぞれの式に $\mathrm{Y}=50$ となる $\mathrm{x}$ 算出したところ、3.062、 1.759、19.12が得られた。従って、空の存在は3.1畳分、直射

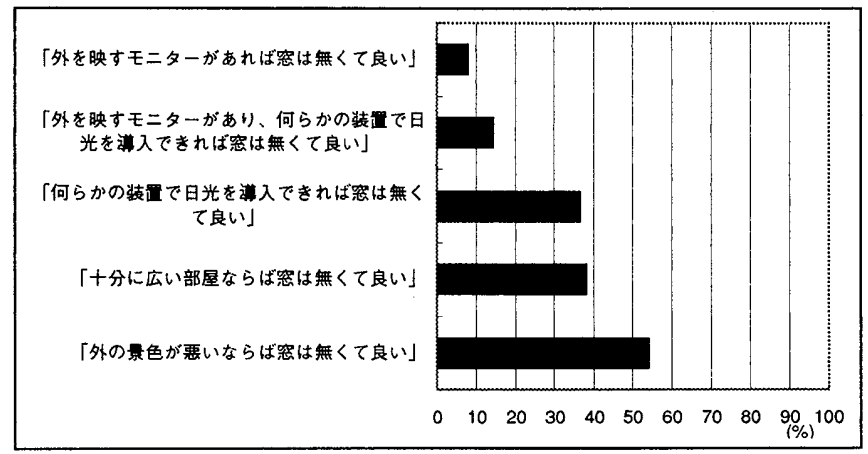

図12 リフレッシュ空間において窓がなくてもよい条件
日光の照射は1.8畳分、美しい景色は19.1盢分のリフレッシュ 時の選択割合の増大の効果があることがわかった。

\section{4 まとめ}

オフィスワーカーを対象とするリフレッシュに関するアン

ケートを行い、下記のことがわかった。

・95.4\%のオフィスワーカーがリフレッシュを必要と思っ ており、実際に $83.7 \%$ $\%$ オフィスでリフレッシュをとっ ている。しかし、リフレッシュに利用できる空閒が不十 分である。

・オフィスに拟てリフレッシュは気分転換や精神疲労 回復に必要であり、特に知的創造業務においては発想転 換に必要と思われている。

・リフレッシュの時の行為は、雑談やボーッとする、飲食す る、喫煙、外の景色を見るである。

・リフレッシュ空間の選択時に、リフレッシュしやすそう な視覚的印象が重要で、それは写真やビデオから目算が つけられる。

・リフレッシュしやすそうな視覚的印象とは、開放感や 居心地の良さ、ゆったりとした感じ、落ち着き、明る さ、自然さなどが近く、にぎわい、豪華、刺激的な感じ などがリフレッシュしにくそうな視覚的印象と近い。

・リフレッシュ空間では光環境が重要で、空が必要であ るが、空を設けられない場合は空間を広くし、日光の導 入装置を設置することで空が無くても可能性がある。

・リフレッシュ空間では、空の存在は3.1畳分、直射日光 の照射は1.8畳分、美しい景色は19.1畳分のリフレッシュ 時の空間選択効果がある。

\section{参考文献}

*1菅谷佐恵子：「オフィスのリフレッシュ空間を考える」建築設備 と配管工事、No. 8、pp. 98 101、1991

*2ニューオフィス推進協議会 : 「平成13年度オフィス実態調査報告 書」ニューオフィス推進協議会、2002

*3大山能永他：「アトリウムの昼光環境に関する研究」日本建築学 学会計画系論文集, No. 503, pp. $69^{\sim} 76,1998$ *4川井淳、石田泰一郎：「室空間への直射光の導入がリフレッシュ 感に与える効果」日本建築学会近畿支部研究報告集、pp. $73^{\sim} 76$ 、 2000

注：アンケートを実施した企業は部課という組織形態をとっ たおらず、部室長以上が労働組合非構成員のために混乱を生 じたらしい。

表3リフレッシュのための空間の

\begin{tabular}{|c|c|c|c|c|c|c|c|c|}
\hline \multirow{2}{*}{6 6 } & & & \multicolumn{3}{|c|}{ 選択割合（\%） } & \multirow[b]{2}{*}{ 3㽬 } & \multirow{3}{*}{$\begin{array}{l}\text { 北密 } \\
\text { (密外の量色は }\end{array}$} & \multirow{3}{*}{\begin{tabular}{|l} 
直射日光は \\
入らない
\end{tabular}} \\
\hline & & 38.7 & vs & 45.1 & & & \\
\hline & \multirow{2}{*}{\multicolumn{2}{|c|}{ 無空 }} & 10.7 & vs & 71.8 & 6畏 & & \\
\hline & & & 11.7 & vivs & 70.8 & 12畺 & 美しくない) & \\
\hline & 北密 & \multirow{3}{*}{$\begin{array}{l}\text { 直射日光は } \\
\text { 入らない }\end{array}$} & 27. 3 & vs & 84. 6 & 3畳 & \multirow{3}{*}{$\begin{array}{l}\text { 南憂 } \\
\text { (㝕外の景色は } \\
\text { 美しくない) }\end{array}$} & \multirow{3}{*}{\begin{tabular}{|l} 
直射日光が \\
入る
\end{tabular}} \\
\hline & (悹外の景色は & & & vs & 78 & 6量 & & \\
\hline & 美しくない) & & & vs & 73.3 & 12㽬 & & \\
\hline & 北言 & 直射日光は & 80. & vs & 1.5 & 3曽 & \multirow{3}{*}{ 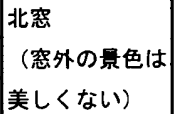 } & \multirow{3}{*}{$\begin{array}{l}\text { 直射日光は } \\
\text { 入らない }\end{array}$} \\
\hline & (密外の景色は & 入らない & 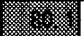 & vs & 0.9 & 6畕 & & \\
\hline & 美しい) & & 10.2) & vs & 11.0 & 12畳 & & \\
\hline
\end{tabular}

[2002年10月18日原稿受理２003年 2 月25日採用決定］ 